\title{
Success Factors and Strategic Planning: Rebuilding an Academic Library Digitization Program
}

This paper discusses a dual approach of case study and research survey to investigate the complex factors in sustaining academic library digitization programs. The case study involves the background of the University of Nevada, Las Vegas (UNLV) Libraries' digitization program and elaborates on the authors' efforts to gain staff support for this program. A related survey was administered to all Association of Research Libraries (ARL) members, seeking to collect baseline data on their digital collections, understand their respective administrative frameworks, and to gather feedback on both negative obstacles and positive inputs affecting their success. Results from the survey, combined with the authors' local experience, point to several potential success factors including staff skill sets, funding, and strategic planning.

$\mathrm{E}$ stablishing a successful digitization program is a dialog and process already undertaken or currently underway at many academic libraries. In 2002, according to an Institute of Museum and Library Services report, "thirty-four percent of academic libraries reported digitization activities within the past 12 months." Nineteen percent expect to be involved in digitization work in the next twelve months, and forty-four percent beyond twelve months. ${ }^{1}$ More current statistics from a subsequent study in 2004 reflected that digitization work has both continued and expanded, with half of all academic libraries performing digitization activities. ${ }^{2}$ Fifty-five percent of ARL libraries responded to a survey informing part of the 2006 Association of Research Libraries (ARL) study Managing Digitization Activities; of these, 97 percent of the respondents indicated engagement in digitization. ${ }^{3}$ The 2008 Ithaka study Key Stakeholders in the Digital Transformation in Higher Education found that nearly 80 percent of large academic libraries either already have or plan to have digital repositories. ${ }^{4}$ With digitization becoming the norm in many institutions, the time is right to consider what factors contribute to the success and rapid growth of some library digitization programs while other institutions find digitization challenging to sustain.

The evolution of digitization at the UNLV Libraries is

Cory Lampert (cory.lampert@unlv.edu) is Digitization Projects Librarian and Jason Vaughan (jason.vaughan@unlv.edu) is Director, Library Technologies, University of Nevada Las Vegas. doubtless a journey many institutions have undertaken. Over the past couple of years, those responsible for such a program at the UNLV Libraries have had the opportunity to revitalize the program and help collaboratively address some key philosophical questions that had not been systematically asked before, let alone answered. Associated with this was a concerted focus to engage other less involved staff. One goal was to help educate them on academic digitization programs. Another goal was to provide an opportunity for input on key questions related to the programs' strategic direction. As a subsequent action, the authors conducted a survey of other academic libraries to better understand what factors have contributed to their programs' own success as well as challenges that have proven problematic. Many questions asked of our library staff in the planning and reorganization process were asked in the survey of other academic libraries. While the UNLV Libraries have undertaken what is felt are the proper structural steps and have begun to author policies and procedures geared toward an efficient operation, the authors wanted to better understand the experiences, key players, and underlying philosophies of other institutional libraries as theses pertain to their own digitization program. The following article provides a brief context relating the background of the UNLV Libraries' digitization program and elaborates on the authors' efforts toward educating library colleagues and gaining staff buy-in for UNLV's digitization program-a process that countless other institutions have no doubt experienced, led, or suffered. The administered survey to ARL members dealt with many topics similar to those that arose during the authors' initial planning and later conversations with library staff, and as such, survey questions and responses are integrated in the following discussion.

The authors administered a 26-question survey to the 123 members of the ARL. The focus of this survey was different from the previously mentioned ARL study Managing Digitization Activities, though several of the questions overlapped to some degree. In addition to demographic or concrete factual types of questions, the UNLV Libraries Digitization Survey had several questions focused on perceptions-that is, staff support, administrative support, challenges, and benefits. Areas of overlap with the earlier ARL survey are mentioned in the appropriate context. Though UNLV isn't a member of the ARL, we consider ourselves a research library, and, regardless, it was a convenient way to provide some structure to the survey. Survey responses were collected for a forty-five-day period from mid-June to late July, 2008. Through visiting each and every ARL library's website, the authors identified the individuals that appeared to be the "leaders" of the ARL digitization programs, with instructions to forward the message to a colleague if 
they themselves had been incorrectly identified. This was very tricky, and revealed numerous program structures in place, differences between institutions in promoting their collections, and so on. The authors didn't necessarily start with the presumption that all ARL libraries even have a digitization program, but most (but not all) either seemed to have a formal organized digitization program with staffing, or at least had digitized and made available something, even if only a single collection. We e-mailed a survey announcement and a link to the survey to the targeted individuals, with a follow-up reminder a month later. Responses were anonymous, and respondents were allowed to skip questions; thus the number of responses for the twenty-six questions making up the survey ranged from a low of thirty (24.4 percent) to a high of forty-four responses (35.8 percent). The average number of responses for each of the questions was 39.8, yielding an overall response rate of 32.4 percent. Questions were of three types: multiple choice (select one answer), multiple choice (mark all that apply), and open text. In addition, some of the multiple choice questions allowed additional open text comments. Survey responses appear in appendix A.

\section{Context of the UNLV Libraries' digitization program}

"Digital collection," for the purpose of the UNLV Library Digitization Survey, was defined as

a collection of library or archival materials converted to machine-readable format to provide electronic access or for preservation purposes; typically, digital collections are library-created digital copies of original materials presented online and organized to be easily searched. They may offer features such as: full text search, browsing, zooming and panning, side by side comparison of objects, and export for presentation and reuse.

One question the survey asked was "what year do you feel your library published its first 'major' digital collection?" Responses ranged from 1990 to 2007; the general average of all responses was 2001. The earlier ARL study found 2000 as the year most respondents began digitization activities. ${ }^{5}$ Mirroring this chronology, the UNLV Libraries has been active in designing digital projects and digitizing materials from library collections since the late 1990s. Technical Web design expertise was developed in the Cataloging unit (later renamed Bibliographic and Metadata Services), and some of the initial efforts were to create online galleries and exhibits of visual materials from Special Collections, such as the Jeanne Russell Janish (1998) exhibit. ${ }^{6}$ Subsequently, the UNLV Libraries purchased the CONTENTdm digital collection management software, providing both back-end infrastructure and front-end presentation for digital collections. Later, the first digitization project with search functionality was created in partnership with Special Collections and was funded by a UNLV Planning Initiative Award received in 1999. The Early Las Vegas (2003) project focused on Las Vegas historical material and was designed to guide users to search, retrieve, and manipulate results using CONTENTdm software to query a database. ${ }^{7}$ UNLV's $^{2}$ development corresponds with regional developments in Utah in 2001, when "the largest academic institutions in Utah were just beginning to develop digital imaging projects." ${ }^{8}$ Data from the 2004 IMLS study showed that, in the twelve months prior to the study release in 2004, the majority of larger academic libraries had digitized between one and five hundred images for online presentation. ${ }^{9}$

In terms of staffing, digitization efforts occur in a wide variety of configurations, from large departments to solo librarians managing volunteers. For institutions with recognized digitization staff, great variations exist between institutions in terms of where in the organizational chart digitization staff are placed. Boock and Vondacek's research revealed that, of departments involved in digitization, special collections, archives, technical services, and newly created digital library units are where digitization activities most commonly take place. ${ }^{10}$ A majority of respondents to the ARL study indicated that some or all activities associated with digitization are distributed across various units in the library. ${ }^{11}$ In 2003, the UNLV Libraries created a formal department within the Knowledge Access Management division-Web and Digitization Services (WDS) - initially comprising five staff focused on the development of the UNLV Libraries' public website, the development of web-based applications and databases to manage and efficiently present information resources, and the digitization and online presentation of library materials unique to the UNLV Libraries' collections and of potential interest to a wider audience. Augmenting their efforts were individuals in other departments helping with metadata standards, content selection, and associated systems technical support. The UNLV Library Digitization Survey showed that the majority (78 percent) of libraries that responded have at least one full-time staff member whose central job responsibility is to support digitization activities. This should not imply the existence of a fully staffed digitization program; the 2006 IMLS study found that 74.1 percent of larger academic libraries described themselves as lacking in sufficiently skilled technology staff to accomplish technology-related activities. ${ }^{12}$

Central to any digitization program should be some structure in terms of how projects are proposed and subsequently prioritized. To help guide the priorities 
of UNLV's infant WDS department, a Digital Projects Advisory Committee was formed to help solicit and prioritize project ideas, and subsequently track the development of approved projects. This committee's work could be judged as having mixed success partly because it met too infrequently, struggled with conflicting philosophical thoughts on digitization, and was confronted with the reality that staff that were needed to help bring approved ideas to fruition simply weren't in place because of too many other library priorities drawing attention away from digitization. An evaluation of the lessons learned from these early years can be found in Brad Eden's article. ${ }^{13}$ The UNLV Library Digitization Survey had several questions related to management and prioritization for digital projects and shows that despite the challenges of a committee-based decisionmaking structure, when a formal process is in place at all, 42.1 percent of survey respondents used a committee versus a single decision maker (23.7 percent) for determining to whom projects are proposed for production. A follow-up question asked "how are approved projects ultimately prioritized?" The most popular response (54.1 percent) indicated "by a committee for review by multiple people," followed by "no formal process" (27 percent). "By a single decision maker" was selected by 18.9 percent of the respondents. The earlier ARL study asked a somewhat related question: "Who makes decisions about the allocation of staff support for digitization efforts? Check all that apply." Out of seven possible responses, the three most popular were "head of centralized unit," "digitization team/committee/working group," and "other person"; the other person was most often in an administrative capacity, such as a dean, director, or department head. ${ }^{14}$

Administrative support for a program was another variable the UNLV Library Digitization Survey investigated. The survey asked respondents to rate, on a scale of one to five, "how would you characterize current support for digitization by your library's administration?" More than 40 percent of responses indicated "consistent support," followed by 31 percent of respondents indicating "very strong support, top priority," 14.3 percent ranking support as neutral, and 14.2 percent claiming "minimal support" or "very little support, or some resistance." It was also clear from some of the other questions' responses that the dean or director's support (or lack thereof) can have dramatic effects on the digitization program. 2005 brought change to the UNLV Libraries in the form of a new dean. Well-suited for the digitization program, she came from California, a state very heavily engaged and at the forefront of digitization within the library and larger academic environment. One of her initiatives was a retooling of the digitization program at the UNLV Libraries, and her enthusiasm reflects a growing awareness of administrators regarding the benefits of digitization.

\section{Reorganization, library staff engagement, and decision making}

In 2006, two new individuals joined UNLV Libraries' Web and Digitization Services Department, the digitization projects librarian (filling a vacancy), and the Web technical support manager (a new position). A bit later, the Systems department (providing technical support for the Web and digitization servers, among other things), and the WDS department were combined into a single unit and renamed Library Technologies. Collectively, these changes brought new and engaged staff into the digitization program and combined under one division many of the individuals responsible for digital collection creation and support. Perhaps more subtlety, this arrangement also provided formal acknowledgement of the importance and desire of publishing digital collections.

With the addition of new staff and a reorganization, a piece still missing was a resuscitation of library stakeholders to help solicit, prioritize, and manage the creation of digital collections and an overall vision guiding the program. While the technical expertise, knowledge of metadata and imaging standards, and deep-rooted knowledge of digitization programs and concepts existed within the Library Technologies staff, other knowledge didn't-primarily in-depth knowledge of the UNLV Libraries' Special Collections and a track record of deep engagement with college faculty and the educational curriculum. Similar to other organizations, the UNLV Libraries had not only created a new unit, but was also poised to introduce cross-departmental project groups that would collaborate on digitization activities. In their study of ARL and Greater Western Library Association (GWLA) libraries, Book and Vondracek found that this was the most commonly used organizational structure. ${ }^{15}$ Knowledge of the concepts of a digitization program and what is involved in digitizing and sustaining a collection was not widespread among other library colleagues. Acknowledged, but not guaranteed up front for the UNLV Libraries, was the likely eventual reformation of a group of interested and engaged library stakeholders charged to solicit, prioritize, and provide oversight of the UNLV Libraries' digitization program. For various reasons, the authors wanted to garner staff buy-in to the highest degree possible. Apart from wanting less informed colleagues to understand the benefits of a digitization program, it was also likely that such colleagues would help solicit projects through their liaison work with programs of study across campus. One UNLV Library Digitization Survey question asked, "how would you characterize support for digitization in your library by the majority of those providing content for digitization projects?" "Consistent support" was indicated by 65.9 percent of respondents; 15.9 percent indicated "very strong support, top priority," 13.6 percent indicated neutrality, and 4.6 
percent indicated either minimal support or even some resistance. To help garner staff buy-in and set the stage for revitalizing the UNLV Libraries' digitization efforts, we began laying the groundwork to educate and engage library staff in the benefits of a digitization program. This work included language successfully woven into the UNLV Libraries' strategic plan and an authored white paper posing engaging questions to the larger library audience related to the strategic direction of the program. Finally, we planned and executed two digitization workshops for library staff.

\section{The strategic plan}

One UNLV Library Digitization Survey question asked, "is the digitization program or digitization activities referenced in your library's strategic plan?" A total of 63.4 percent indicated yes, with an additional 22 percent indicating no specific references, but rather implied references. Only 7.3 percent indicated that the digitization program was not referenced in any manner in the strategic plan, while, surprisingly, 3 responses (7.3 percent) indicated that their library doesn't have a strategic plan. The UNLV Libraries' strategic plan is an important document authored with wide feedback from library staff, and it exemplifies the participatory decision-making process in place in the library. The current iteration of the strategic plan covers 2007-9 and includes various goals with supporting strategies and action items. ${ }^{16}$ In addition, all action items have associated assessment metrics and library staff responsible for championing the action items. Departmental annual reports explicitly reference progress toward strategic plan goals. As such, if goals related to the digitization program appear in the strategic plan, that's a clear indication, to some degree, of staff buy-in in acknowledging the significance of the digitization program. Fortunately, digitization efforts figure prominently in several goals, strategies, and action items, including the following:

- Increasingly provide access to digital collections and services to support instruction, research, and outreach while improving access to the UNLV Libraries' print and media collections.

- Provide greater access to digital collections while continuing to build and improve access to collections in all formats to meet the research and teaching needs of the university. Identify collections to digitize that are unique to UNLV and that have a regional, national, and international research interest. Create digital projects utilizing and linking collections. Develop and adapt metadata and scanning standards that conform to national standards for all formats. Provide content and metadata for regional and national digital projects. Continue to develop expertise in the creation and management of digital collections and information. Collaborate with faculty, students, and others outside the library in developing and presenting digital collections.

- Be a comprehensive resource for the documentation, investigation, and interpretation of the complex realities of the Las Vegas metropolitan area and provide an international focal point for the study of Las Vegas as a unique urban and cultural phenomenon. Facilitate real and digital access to materials and information that document the historical, cultural, social, and environmental setting of Las Vegas and its region by identifying, collecting, preserving, and managing information and materials in all formats. Identify unique collections that strengthen current collections of national and international significance in urban development and design, gaming, entertainment, and architecture. Develop new access tools and enhance the use of current bibliographic and metadata utilities to provide access to physical and digital collections. Develop Web-based digital projects and exhibits based upon the collections.

An associated capital campaign case statement associated with the strategic plan lists several gift opportunities that would benefit various aspects of the UNLV Libraries; several of these include gift ideas related to the digitization of materials.

\section{The white paper}

Another important step in laying the groundwork for the digitization program was a comprehensive white paper authored by the recently hired digitization projects librarian. The finished paper was originally given to the dean of libraries and thereafter to the administrative cabinet, and eventually distributed to all library staff. The outline of this white paper is provided as appendix B. The purpose of the white paper was multifaceted. After a brief historical context, the white paper addressed perhaps the single most important aspect of a digitization program-program planning-developing the strategic goals of the program, selecting and prioritizing projects though a formal decision-making process, and managing initiatives from idea to reality through efficient project teams. This first topic addressing the core values of the program had a strong educational purpose for the entire library staff-the ultimate audience of the paper. As part of its educational goal, the white paper enumerated the various strengths of digitization and why an institution 
would want to sustain a digitization program (providing greater worldwide access to unique materials, promoting and supporting education and learning when integrated with the curriculum, etc.). It defined distinctions between an ephemeral digital exhibit and a long-term published and maintained collection. It discussed the various components of a digital collection-images, multimedia, metadata, indexing, thematic presentation (and the preference to be unbiased), integration with other digital collections and the library website, etc. It posited important questions on sustenance and assessment, and defined concepts such as refreshing of data and migration of data to help set the stage for future philosophical discussions.

Given the myriad reasons one might want to publish a digital collection, checked by the reality that all the reasons and advantages may not be realized or given equal importance, the white paper listed several scenarios and asked if each scenario was a strong underlying goal for our program-in short, true or false:

- "The libraries are interested in digitizing select unique items held in our collection and providing access to these items in new formats."

- "The Libraries are interested in digitizing whole runs of an information resource for access in new formats."

- "The Libraries should actively pursue funding to support major digitization initiatives."

- "The Libraries should take advantage of the unique publicity, promotion, and marketing opportunities afforded by a digital project/program."

Continuing with a purpose of defining boundaries of the new program, the paper asked questions related to audience, required skill sets, and resources.

The second primary topic introduced the selection and prioritization of the items and ideas suggested for digitization. It posed questions related to content criteria (Why does this idea warrant consideration? Would complex or unique metadata be required from a subject specialist?) and listed various potential evaluative measures of project ideas (Should we do this if another library is already doing a very similar project?). Technical criteria considerations were enumerated, touching on interoperability of collections in different formats, technical infrastructure considerations, and so on. Multiple simultaneous ideas beg for prioritization, and the white paper proposed a formal review process and the library staff and skill sets that would help make such a process successful.

The third primary topic focused on the details of carrying an approved idea to reality, and strengthened the educational purpose of the white paper. It described the general planning steps for an approved project and included a list of typical steps involved with most digital projects-scanning; creating metadata, indexes, and controlled vocabulary; coding and designing the Web interface; loading records into UNLV Libraries' CONTENTdm system; publicizing the launch of the project; and assessing the project after completion. One UNLV Library Digitization Survey question was related to thirteen such skills the UNLV Libraries identified as critical for a successful digitization program. The question asked respondents to rate skill levels possessed by personnel at their library, based on a five-point scale (from one to five: "no expertise," "very limited expertise," "working knowledge/enough to get by," "advanced knowledge," and "tremendous expertise"). Neither "no expertise" nor "very limited expertise" garnered the highest number of responses for any of the skills. The overall rating average of all thirteen skills was 3.79 out of 5 . The skills with the highest rating averages were "metadata creation/cataloging" 4.4 and "digital imaging/document scanning/post image processing/photography" with 4.27 . The skills with the lowest rating averages were "marketing and promotion" with 2.95 followed by "multimedia formats" with 3.33 .

The UNLV Libraries' white paper contained several appendixes that likely provided some of the richest content of the white paper. With the educational thrust completed, the appendixes drew a roadmap of "where do we want to go from here?" This roadmap suggested the revitalization of an overarching Digital Projects Advisory Committee, potential members of the committee, and functions of the committee. The committee would be responsible for soliciting and prioritizing ideas and tracking the progress of approved ideas to publication. The appendixes also proposed project teams (which would exist for each project), likely members of the project teams, and the functions of the project team to complete day-to-day digitization activities. The liaison between the Digital Projects Advisory Committee and the project team would be the digitization projects librarian, who would always serve on both. The last page of the white paper provided an illustration highlighting the various steps proposed in the lifecycle of a digital project-from concept to reality.

\section{Digitization workshops}

Several months after the white paper had been shared, the next step in restructuring the program and building momentum was sponsoring two forums on digitization. The first one occurred in November 2006 and included two speakers brought in for the event, Roy Tennant (formerly user services architect with the California Digital Library and now with OCLC) and Ann Lally (head of the Digital Initiatives program at the University of Washington Libraries). This session consisted of a 
two-hour presentation and Q\&A to which all library staff were invited, followed by two breakout sessions. All three sessions were moderated by the digitization projects librarian. Questions from these sessions are provided in appendix $C$. The breakout sessions were each targeted to specific departments in the UNLV Libraries. The first focused on providing access to digital collections (definitions of digital libraries, standards, designing useful metadata, accessibility and interoperability, etc.). The second focused on components of a well-built digital library (goals of a digitization program, content selection criteria, collaboration, evaluation and assessment, etc.). Colleagues from other libraries in Nevada were invited, and the forum was well attended and highly praised. The sessions were recorded and later made available on DVD for library staff unable to attend. This initial forum accomplished two important goals. First, it was an allstaff meeting offering a chance to meet, explore ideas, and learn from two well-known experts in the field. Second, it offered a more intimate chance to talk about the technical and philosophical aspects of a digitization program for those individuals in the UNLV Libraries associated with such tasks. As a momentum-building opportunity for the digitization program, the forum was successful.

The second workshop occurred in April 2007. To gain initial feedback on several digitization questions and to help focus this second workshop, we sent out a survey to several dozen library staff-those that would likely play some role at some point in the digitization program. The survey contained questions focused on several thematic areas: defining digital libraries, boundaries to the digitization program, users and audience, digital project design, and potential projects and ideas. It contained thirteen questions consisting of open-ended response questions, questions where the respondent ranked items on a five-point scale, and "select all that apply"-type questions. We distributed the survey to invitees to the second workshop, approximately three dozen individuals; of those, eighteen (about 50 percent) responded to most of the questions. The survey was closely tied to the white paper and meant to gauge early opinions on some of the questions posed by that paper. Whereas the first workshop included some open Q\&A, the second session was structured as a hands-on workshop to answer some of the digitization questions and to illustrate the complexity of prioritizing projects. The second workshop began with a status update on the retooling of the UNLV Libraries' digitization program. This was followed by an educational component that focused on a diagram that detailed the workflow of a typical digitization project and who was involved and that emphasized the fact that there is a lot of planning and effort needed to bring an idea to reality. In addition, we discussed project types and how digital projects can vary widely in scope, content, and purpose. Finally, we shared general results from the aforementioned survey to help set the stage for the structured hands-on exercises. The outline for this second workshop is provided in appendix D.

One question of the UNLV Library Digitization Survey asked, "on a scale of 1 to 5, how important are each of the factors in weighing whether to proceed with a proposal for a new digital collection project, or enhancement of an existing project?" Eight factors were listed, and the fivepoint scale was used (from one to five: "not important," "less important," "neutral," "important," and "vitally important"). The average rating for all eight factors was 3.66. The two most important factors were "collection includes unique items" (4.49 average rating) and "collection includes items for which there is a preservation concern or to make fragile items more accessible to the public" (3.95 average rating). The factors with the lowest average ratings were "collection includes integration of various media into a themed presentation" (2.54 average rating) followed by "collection involves a whole run of an information resource (i.e., such as an entire manuscript, newspaper run, etc." (3.39 average rating). The earlier ARL survey asked a somewhat related question, "What is/has been the purpose of these digitization efforts? Check all that apply." Of the six possible responses (which differed somewhat from those in the UNLV Library Digitization Survey), the most frequent responses were "improved access to library collections," "support for research," and "preservation."17 The earlier survey also asked the question, "What are the criteria for selecting material to be digitized? Check all that apply." The most frequent responses were "subject matter," "material is part of a collection being digitized," and "rarity or uniqueness of the item(s)."18

The first exercise of the second digitization workshop focused on digital collection brainstorming. The authors provided a list of ten project examples and asked each of the six tables (with four colleagues each) to prioritize the ideas. Afterward, a speaker from each table presented the prioritizations and defended their rankings. This exercise successfully illustrated to peers in attendance that different groups of people have different ideas about what's important and what constitutes prime materials for digitization. The rankings from the varying tables were quite divergent. A related question asked of the ARL libraries in the UNLV Library Digitization Survey was "from where have ideas originated for existing, published digital collection at your library?" and offered six choices. Respondents could mark multiple items. The most chosen answer (92.7 percent) was "special collections, archives, or library with a specialized collection or focus." The least chosen answer (51.2 percent) was "an external donor, friend of the library, community user, etc." For the second part of the workshop exercise, each table came up with their own digital collection ideas, defined the audience and content of the proposal, and defended and 
explained why they thought these were good proposals. Fourteen unique and varied ideas were proposed, most of which were tightly focused on Las Vegas and Nevada, such as "History of Las Vegas," "UNLV Yearbooks," "Las Vegas Gambling and Gamblers," and "African American Entertainers in Las Vegas." Other proposals were less tied to the area, such as a "Botany Collection," "Movie Posters," "Children's Literature," "Architecture," and "Federal Land Management." This exercise successfully showed that ideas for digital collections stretch across a broad spectrum, as broad as the individual brainchilden themselves.

Finally, in the last digitization workshop exercise, each table came up with specialties, roles, and skills of candidates who could potentially serve on the proposed committee, and defended their rationale-in other words, committee success factors. This exercise generated nineteen skills seen as beneficial by one or more of the group tables. At the end of the workshop, we asked if others had alternate ideas to the proposed committee. None surfaced, and the audience thought such a committee should be reestablished. This second workshop concluded with a brief discussion on next steps-drafting a charge for the committee, choosing members, and a plug for the expectation of subject liaisons working with their respective areas to help better identify opportunities for collaboration on digital projects across campus.

\section{Toward the future}

Digital projects currently maintained by the UNLV Libraries include both static Web exhibits in the tradition of UNLV's first digitization efforts, as well as several searchable CONTENTdm-powered collections. The UNLV Libraries have also sought to continue collaborative efforts, participating as project partners for the Western Waters Digital Library (phase 1) and continuing in a regional collaboration as a hosting partner in the Mountain West Digital Library. Partnerships were shown in the UNLV Library Digitization Survey to garner increased buy-in for projects, with one respondent commenting that faculty partnerships had been "the biggest factor for success of a digital library project." Institutional priorities at UNLV Libraries reflect another respondent's comment regarding "interesting archival collections" as a success factor. One recently launched UNLV collection is the Showgirls collection (2006), focused on a themed collection of historical material about Las Vegas entertainment history. ${ }^{19}$ Another recently launched collection, the Nevada Test Site Oral History Project (2008), recounts the memories of those affiliated with and affected by the Nevada Test Site during the era of Cold War nuclear testing and includes searchable transcripts, selected audio and video clips, and scanned photographs and images. ${ }^{20}$

With general library approval, the restructured Digitization Projects Advisory Committee was established in July 2007 with six members drawn from Library Technologies, Special Collections, the subject specialists, and at large. The advisory committee has drafted and gained approval for several key documents to help govern the committee's future work. This includes a collection development policy for digitization projects and a project proposal form to be completed by the individual or group proposing an idea for a digital collection. At the time of writing, the committee is just now at the point of advertising the project proposal form and process, and time will tell how successful these documents prove. In the UNLV Library Digitization Survey, 65.4 percent responded that a digitization mission statement or collection development policy was in place at their institution. One goal at UNLV is to "ramp up" the number of simultaneous digitization projects underway at any one time at UNLV. Many items in the Special Collections are ripe for digitization. Many of these are uncataloged, and digitizing such collections would help promote these hidden treasures. Related to ramping up production, one UNLV Library Digitization Survey question asked, "on average over the past three years, approximately how many NEW digital collections are published each year?" Responses ranged from zero new collections to sixty. The average number of new collections added each year was 6.4 for the 32 respondents who gave exact numerical answers. While this is perhaps double the UNLV Libraries' current rate of production, it illustrates that increasing production is an achievable goal.

Staffing and funding for the UNLV Libraries' digitization program have both seen increases over the past several years. A new application developer was hired, and a new graphics/multimedia specialist filled an existing vacancy. Together, these staff have helped with projects such as modifying CONTENTdm templates, graphic design, and multimedia creation related to digital projects, in addition to working on other Web-based projects not necessarily related to the digitization program. Another position has a job focus shifted toward usability for all things Webbased, including digitization projects. In terms of funding, the two most recent projects at the UNLV Libraries are both the result of successful grants. The recently launched Nevada Test Site Oral History Project was the result of two grants from the U.S. Departments of Education and Energy. Subsequently, a \$95,000 LSTA grant proposal seeking to digitize key items related to the history of southern Nevada from 1900 to 1925 was funded for 2008-9, with the resulting digital collection publicly launched in May 2009. This collection, Southern Nevada: The Boomtown Years, contains more than 1,500 items from several institutions, focused on the heyday of mining town life in Southern 
Nevada during the early twentieth century. ${ }^{21}$ This grant funded four temporary positions: a metadata specialist, an archivist, a digital projects intern, and an education consultant to help tie the digitized collection into the $\mathrm{K}-12$ curriculum.

Grants will likely play a large role in the UNLV Libraries' future digitization activities. The UNLV Library Digitization Survey asked, "Has your institution been the recipient of a grant or gift whose primary focus was to help efforts geared toward digitization of a particular collection or to support the overall efforts of the digitization program?" The question sought to determine if grants had played a role, and if so, whether it was primarily large grants (defined as > $\$ 100,000)$, small grants $(<\$ 100,000)$, or both. The majority of responses (46.2 percent), indicated a combination of both small and large grants had been received in support of a project or the program. An additional 25.6 percent indicated that large grants had played a role, and 23.1 percent indicated that one or more small grants had played a role. Two respondents (5.1 percent) indicated that no grants had been received or that they had not applied for any grants. The earlier ARL survey asked the question, "What was/is the source of the funds for digitization activities? Check all that apply." Of seven possible responses, "grant" was the second most frequent response, trailing only "library." 22

With an eye toward the future, the survey administered to ARL libraries asked two blunt questions summarizing the overall thrust of the survey. One of the final open-ended survey questions asked, "What are some of the factors that you feel have contributed to the success of your institution's digitization program?" Forty respondents offered answers that ranged from listing one item to multiple items. Several responses along the same general theme seemed to surface, which could be organized into rough clusters. In general, support from library administration was mentioned by a dozen respondents, with such statements as "consistent interest on the part of higher level administration," "having support for the digitization program at an administrative level from the very beginning," "good support from the library administration," "support of the dean," and, mentioned multiple times in the same precise language, "support from library administration." Faculty collaboration and interest across campus was mentioned by ten respondents, evidenced by statements such as "strong collaboration with faculty partners," "support of faculty and other partners," "interest from faculty," "heavily involving faculty in particular ... ensures that we can have continued funding since the faculty can lobby the Provost's office," and "grant writing partnerships with faculty." Passionate individuals involved with the program and/or support from other staff in the libraries were mentioned by ten respondents, with comments such as "program management is motivated to achieve success," "a strong department head," "individual staff member's dedication to a project," "commitment of the people involved," "team work, different departments and staff willing to work together," and "supportive individuals within the library." Having "good" content to digitize was mentioned by seven respondents, with statements such as "good content," "collection strength," "good collections," and "availability of unique source materials." Strategic plan or goals integration was mentioned in several responses, such as "strong financial commitment from the strategic plan" and "mainstreaming the work of digital collection building into the strategic goals of many library departments." Successful grants and donor cultivation were mentioned by four respondents. Other responses were more unique, such as one respondent's one-word response- "luck" - and other responses such as "nimbleness, willingness, and creativity," and "a vision for large-scale production, and an ability to achieve it."

The final UNLV Library Digitization Survey question asked, "What are the biggest challenges for your institution's digitization program?" Thirty-nine respondents provided feedback, and again, several variations on a theme emerged. The most common response, unsurprisingly, "not enough staffing," was mentioned by eighteen respondents, with responses such as "lack of support for staffing at all necessary levels," "the real problem is people, we don't have enough staff," "limited by staff," and "we need more full-time people." Following this was (a likely related response) "funding," mentioned by another nine respondents, with statements such as "funding for external digitization," "identifying enough funding to support conversion," "we could always use more money," and, succinctly, "money." Related to staffing, specifically, six responses focused on technical staff or support from technical staff, such as "need more IT (information technology) staff," "need support from existing IT staff," "not enough application development staff," and "limited technical expertise." Prioritization and demand issues surfaced in six responses, with responses such as "prioritizing efforts now that many more requests for digital projects have been submitted," "prioritization," "can't keep up with demand," and "everyone wants to digitize everything." Workflow was mentioned in four responses, such as "workflow bottlenecks," "we need to simplify the process of getting materials into the repository," and "it takes far longer to describe an object than to digitize it, thus creating bottlenecks." "Not enough space" was mentioned by three respondents, and "maintaining general librarywide staff support for the program" was mentioned by two respondents. The UNLV Libraries will keep in mind the experiences of our colleagues, as few, if any, libraries are likely immune to similar issues. 


\section{Conclusions}

The UNLV Library Digitization Survey revealed, not surprisingly, that not all libraries, even those of high stature, are created equally. Many have struggled to some extent in growing and sustaining their digitization programs. Many have numerous published projects, others have few or perhaps even none. Administrative and fellow colleague support varies, as does funding. Additional questions remain to be tackled at the UNLV Libraries. How precisely will we define success for the digitization program? By the number of published collections? By the number of successful grants executed? By the number of image views or metadata record accesses? By the frequency of press in publications and word-of-mouth praise from fellow colleagues? Ideas abound, but no definitive answers exist as of yet. At the larger level, other questions are looming. As libraries continue to promote themselves as relevant in the digital age, and promote themselves as a (or the) central partner in student learning, to what degree will libraries' digital collections be tied into the educational curriculum, whether at their own affiliated institutions or with $\mathrm{K}-12$ in their own states as well as beyond? Clearly the profession is changing, with library schools creating courses and certificate programs in digitization. Discussions about the integration of various information silos, metadata crosswalking, and item exposure in other online systems used by students will continue. Library digitized collections are primary resources involved in such discussions. While these questions persist, it's hoped that at a minimum, the UNLV Libraries have established the foundational structure to foster what we hope will be a successful digitization program.

\section{References}

1. Institute for Museum and Library Services, "Status of Technology and Digitization in the Nation's Museums and Libraries 2002 Report," May 23, 2002, www.imls.gov/publications/ TechDig02/2002Report.pdf (accessed Mar. 1, 2009).

2. Institute for Museum and Library Services, "Status of Technology and Digitization in the Nation's Museums and Libraries 2006 Report," Jan. 2006, www.imls.gov/resources/ TechDig05/Technology\%2BDigitization.pdf (accessed Mar. 1, 2009).

3. Rebecca Mugridge, Managing Digitization Activities, SPEC Kit 294 (Washington, D.C.: Association of Research Libraries, 2006): 11.
4. Ross Housewright and Roger Schonfeld, "Ithaka's 2006 Studies of Key Stakeholders in the Digital Transformation in Higher Education," Aug. 18, 2008, www.ithaka.org/research/ Ithakas $\% 202006 \% 20$ Studies $\% 20$ of $\% 20$ Key $\% 20$ Stakeholders $\% 20$ in $\% 20$ the $\% 20$ Digital\%20Transformation\%20in $\% 20$ Higher $\% 20$ Education.pdf (accessed Mar 1, 2009).

5. Ibid.

6. University of Nevada, Las Vegas University Libraries, "Jeanne Russell Janish, Botanical Illustrator: Landscapes of China and the Southwest," Oct. 17, 2006, http://library.unlv .edu/speccol/janish/index.html (accessed Mar. 1, 2009).

7. University of Nevada, Las Vegas University Libraries, "Early Las Vegas," http://digital.library.unlv.edu/early_ las_vegas/earlylasvegas/earlylasvegas.html (accessed Mar. 1, 2009).

8. Arlitsch, Kenning, and Jeff Jonsson, "Aggregating Distributed Digital Collections in the Mountain West Digital Library with the CONTENTdm Multi-site Server," Library Hi Tech 23, no. 2 (2005): 221.

9. Institute for Museum and Library Services, "Status of Technology and Digitization in the Nation's Museums and Libraries 2006 Report."

10. Michael Boock and Ruth Vondracek, "Organizing for Digitization: A Survey," portal: Libraries and the Academy 6, no. 2 (2006), http://muse.jhu.edu/journals/portal_libraries_and_ the_academy/v006/6.2boock.pdf (accessed Mar. 1, 2009).

11. Mugridge, Managing Digitization Activities, 12.

12. Institute for Museum and Library Services, "Status of Technology and Digitization in the Nation's Museums and Libraries 2006 Report."

13. Brad Eden, "Managing and Directing a Digital Project," Online Information Review 25, no. 6 (2001), www.emerald insight.com/Insight/viewPDF.jsp? contentType=Article \& Filename $=$ html $/$ Output $/$ Published $/$ EmeraldFullTextArticle / Pdf/2640250607.pdf (accessed Mar. 1, 2009).

14. Mugridge, Managing Digitization Activities, 32-33.

15. Boock and Vondracek, "Organizing for Digitization: A Survey."

16. University of Nevada, Las Vegas University Libraries, "University Libraries Strategic Goals and Objectives," June 1, 2005, www.library.unlv.edu/about/strategic_goals.pdf (accessed Mar. 1, 2009).

17. Mugridge, Managing Digitization Activities, 20.

18. Ibid, 48 .

19. University of Nevada, Las Vegas University Libraries, "Showgirls," http://digital.library.unlv.edu/showgirls / (accessed Mar. 1, 2009).

20. University of Nevada, Las Vegas University Libraries, "Nevada Test Site Oral History Project," http://digital.library .unlv.edu/ntsohp/ (accessed Mar. 1, 2009).

21. University of Nevada, Las Vegas University Libraries, "Southern Nevada: The Boomtown Years," http://digital .library.unlv.edu/boomtown/ (accessed May 15, 2009).

22. Mugridge, Managing Digitization Activities, 40. 


\section{APPENDIX A. UNLV library digitization survey responses}

1. Is the digitization program or digitization activities referenced in your library's strategic plan?

\begin{tabular}{lcc}
\hline Answer Options (41 responses total) & $\begin{array}{c}\text { Response } \\
\text { Percent }\end{array}$ & $\begin{array}{c}\text { Response } \\
\text { Count }\end{array}$ \\
\hline Yes & 63.4 & 26 \\
No & 7.3 & 3 \\
Not specifically, but implied & 22.0 & 9 \\
Our library doesn't have a strategic plan & 7.3 & 3 \\
\hline
\end{tabular}

2. How would you characterize current support for digitization by your library's administration?

\begin{tabular}{lcc}
\hline Answer Options (42 responses total) & $\begin{array}{c}\text { Response } \\
\text { Percent }\end{array}$ & $\begin{array}{c}\text { Response } \\
\text { Count }\end{array}$ \\
\hline Very strong support, top priority & 31.0 & 13 \\
Consistently supportive & 40.5 & 17 \\
Neutral & 14.3 & 6 \\
Minimal support, & 7.1 & 3 \\
Very little support, or some resistance & 7.1 & 3 \\
\hline
\end{tabular}

3. How would YOU characterize support for digitization in your library by the majority of those providing content for digitization projects (i.e., regardless of whether those providing content have as a primary or a minor responsibility provisioning content for digitization projects)?

\begin{tabular}{lcc}
\hline Answer Options (44 responses total) & $\begin{array}{c}\text { Response } \\
\text { Percent }\end{array}$ & $\begin{array}{c}\text { Response } \\
\text { Count }\end{array}$ \\
\hline Very strong support, top priority & 15.9 & 7 \\
Consistently supportive & 65.9 & 29 \\
Neutral & 13.6 & 6 \\
Minimal support & 2.3 & 1 \\
Very little support, or some resistance & 2.3 & 1 \\
\hline
\end{tabular}


4. What year do you feel your library published its first "major" digital collection? Major is defined as this was the first project deemed as having permanence and which would be sustained; it has associated metadata, etc. If you do not know, you may estimate or type "Unknown."

Responses ranged from 1990 to 2007.

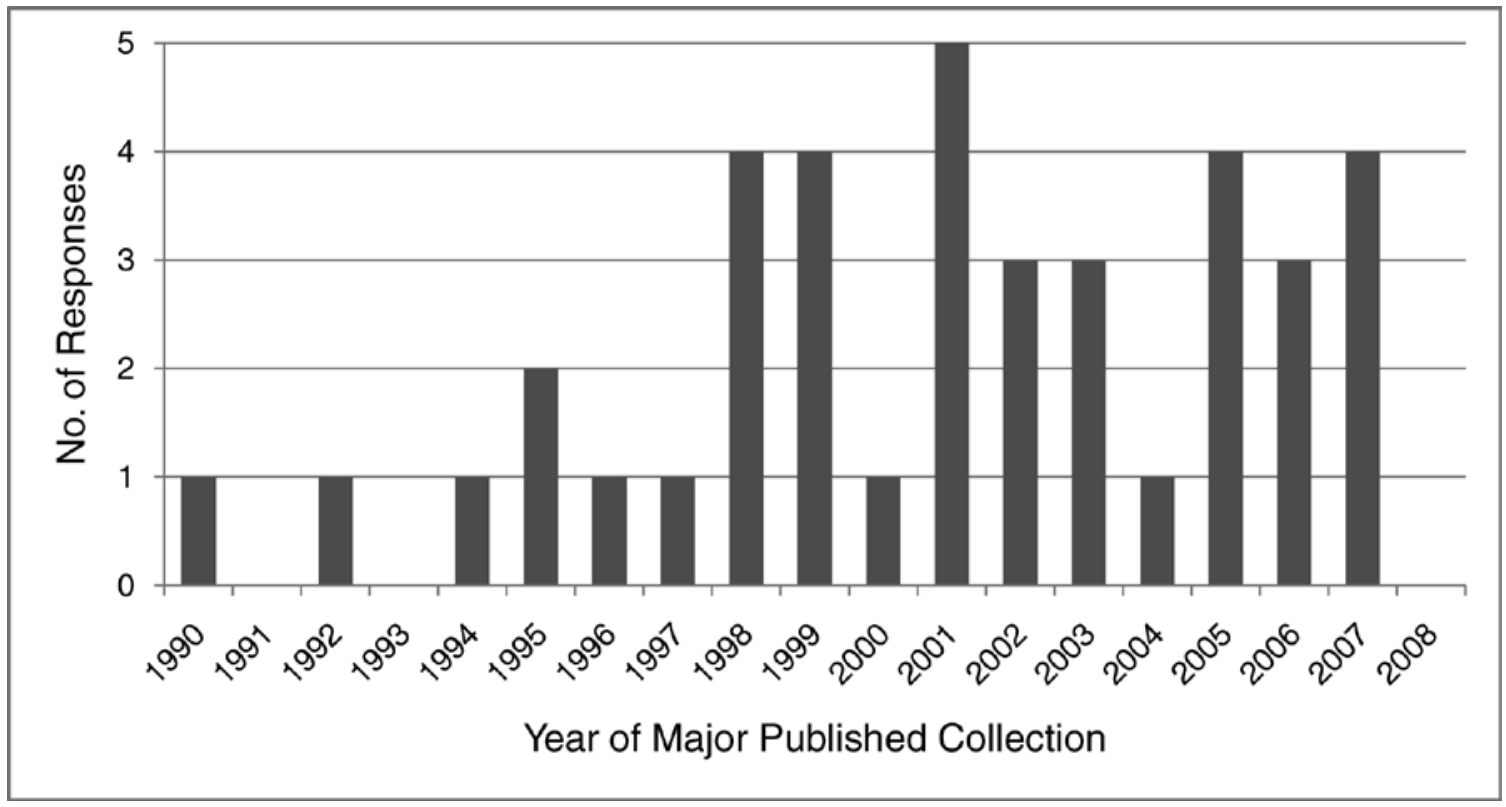

5. To date, approximately how many digital collections has your library published? (Please do not include ephemeral exhibits that may have existed in the past but no longer are present or sustained.)

Responses ranged from 1 to 1,000s. The great majority of responses were under 100; four responses were between 100 and 200 , and one response was "1,000s."

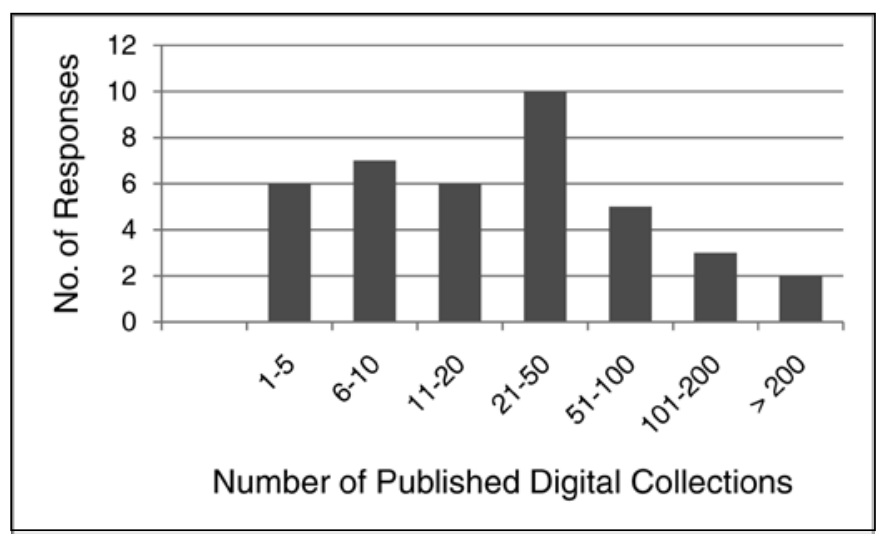


6. On average over the past 3 years, approximately how many NEW digital collections are published each year?

All but two responses ranged from 0 to 10. One response was 13, one was 60 .

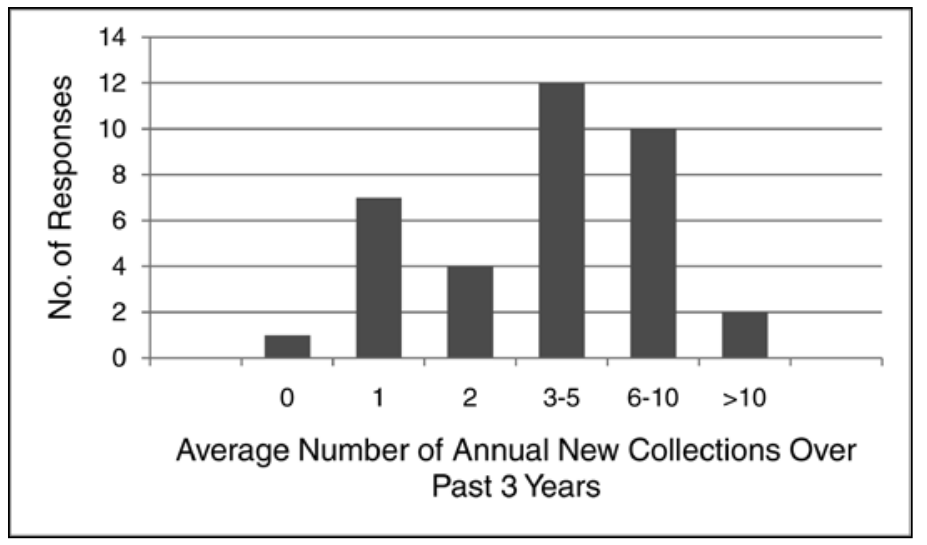

7. What hosting platform(s) do you use for your digital collections (e.g., CONTENTdm, etc.)?

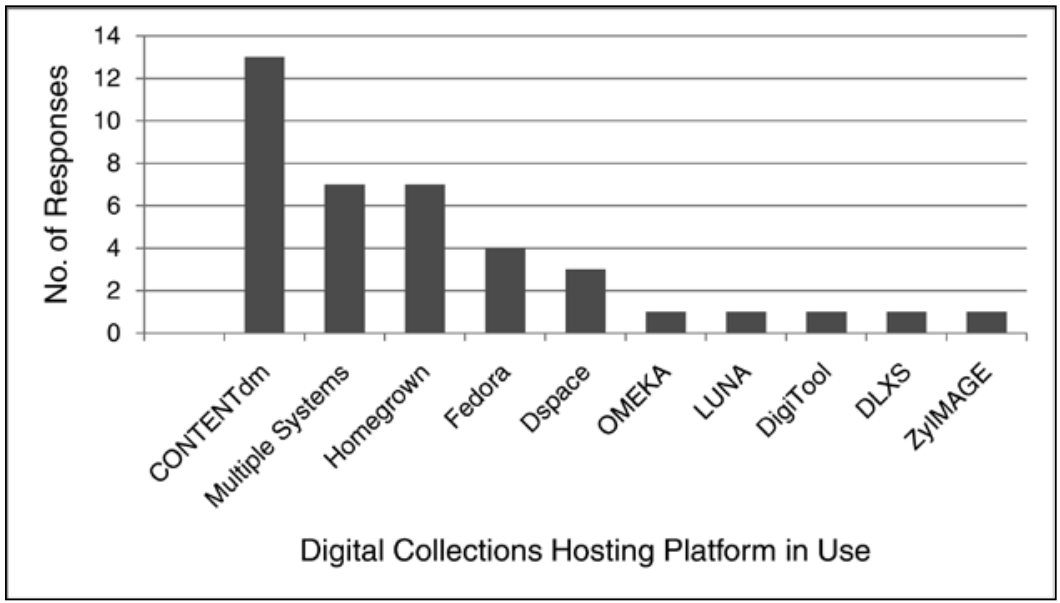

8. Does your institution have an institutional repository (e.g., DSpace)?

\begin{tabular}{lcc}
\hline $\begin{array}{l}\text { Answer Options } \\
\text { (41 responses total) }\end{array}$ & $\begin{array}{c}\text { Response } \\
\text { Percent }\end{array}$ & $\begin{array}{c}\text { Response } \\
\text { Count }\end{array}$ \\
\hline Yes & 73.2 & 30 \\
No & 26.8 & 11 \\
\hline
\end{tabular}

9. If the answer was "yes" in question 5, is your institutional repository using the same software as your digital collections?

\begin{tabular}{lcc}
\hline $\begin{array}{l}\text { Answer Options } \\
\text { (30 responses total) }\end{array}$ & $\begin{array}{c}\text { Response } \\
\text { Percent }\end{array}$ & $\begin{array}{c}\text { Response } \\
\text { Count }\end{array}$ \\
\hline Yes & 26.7 & 8 \\
No & 73.3 & 22 \\
\hline
\end{tabular}


10. Is there an individual at your library whose central job responsibility is the development, oversight, and management of the library's digitization program? (For purposes of this survey, central job responsibility means that 50 percent or more of the employee's time is dedicated to digitization activities.)

\begin{tabular}{lcc}
\hline $\begin{array}{l}\text { Answer Options } \\
\text { (38 responses total) }\end{array}$ & $\begin{array}{c}\text { Response } \\
\text { Percent }\end{array}$ & $\begin{array}{c}\text { Response } \\
\text { Count }\end{array}$ \\
\hline Yes & 78.9 & 30 \\
No & 21.1 & 8 \\
\hline
\end{tabular}

11. Are there regular, full-time staff at your library who have as their primary or one of their primary job responsibilities support of the digitization program? For this question, a primary job responsibility means that at least 20 percent of their normal time is spent on activities directly related to supporting the digitization program or development of a digital collection. (Mark all that apply)

\begin{tabular}{lcc}
\hline Answer Options (39 responses total) & $\begin{array}{c}\text { Response } \\
\text { Percent }\end{array}$ & $\begin{array}{c}\text { Response } \\
\text { Count }\end{array}$ \\
\hline Digital imaging/document scanning, post-image & 82.1 & 32 \\
processing, photography & 79.5 & 31 \\
Metadata creation/cataloging & 28.2 & 11 \\
Archival research of documents included in a & 53.8 & 21 \\
collection(s) & 23.1 & 9 \\
Administration of the hosting server & 61.5 & 24 \\
Grant writing/donor cultivation/program or collection & 25.6 & 10 \\
marketing & 53.8 & 21 \\
Multimedia formats & & \\
Database design and data manipulation & 64.1 & 25 \\
Maintenance, customization, and/or configuration of \\
digital asset management software or features within \\
that software (e.g., CONTENTdm) & & 12 \\
Programming languages & 30.8 & 28 \\
Web design and development & 71.8 & 10 \\
Usability & 25.6 & 11 \\
Marketing and promotion & 28.2 & 2.6 \\
None of the above & & 1 \\
\hline
\end{tabular}

12. Approximately how many individuals not on the full-time library staff payroll (i.e., student workers, interns, fieldworkers, volunteers) are currently working on digitization projects?

Answers ranged from 0 to "approximately 46." The majority of responses (24) fell between 0 and 10 workers; twelve responses indicated more than 10; several responses indicated "unknown." 
13. Has your library funded staff development, training, or conference opportunities that directly relate to your digitization program and activities for one or more library staff members?

\begin{tabular}{lcc}
\hline Answer Options (41 responses total) & $\begin{array}{c}\text { Response } \\
\text { Percent }\end{array}$ & $\begin{array}{c}\text { Response } \\
\text { Count }\end{array}$ \\
\hline $\begin{array}{l}\text { Yes, frequently, one or more staff have been funded by } \\
\text { library administration for such activities }\end{array}$ & 48.8 & 20 \\
$\begin{array}{l}\text { Yes, occasionally, one or more staff have been funded } \\
\text { by library administration for such activities }\end{array}$ & 51.2 & 21 \\
$\begin{array}{l}\text { No, to the best of my knowledge, no library staff } \\
\text { member has been funded for such activities }\end{array}$ & 0.0 & 0 \\
\hline
\end{tabular}

14. Where does the majority of digitization work take place?

\begin{tabular}{lcc}
\hline Answer Options (41 responses total) & $\begin{array}{c}\text { Response } \\
\text { Percent }\end{array}$ & $\begin{array}{c}\text { Response } \\
\text { Count }\end{array}$ \\
\hline $\begin{array}{l}\text { Centralized in the library (majority of content digitized } \\
\text { using library staff and equipment in one department) }\end{array}$ & 48.8 & 20 \\
$\begin{array}{l}\text { Decentralized (majority of content digitized in multiple } \\
\text { library departments or outside the library by other }\end{array}$ & 12.2 & 5 \\
$\begin{array}{l}\text { university entities) } \\
\text { Through vendors or outsourcing }\end{array}$ & 7.3 & 3 \\
Hybrid of approaches depending on project & 31.7 & 13 \\
\hline
\end{tabular}

15. On a scale of 1 to 5 ( 1 being least important and 5 being vitally important), how important are each of the factors in weighing whether to proceed with a proposal for a new digital collection project or enhancement of an existing project?

\begin{tabular}{|c|c|c|c|c|c|c|c|}
\hline $\begin{array}{l}\text { Answer Options } \\
\text { (41 responses total) }\end{array}$ & $\begin{array}{c}\text { Not } \\
\text { Important }\end{array}$ & $\begin{array}{l}\text { Less } \\
\text { Important }\end{array}$ & Neutral & Important & $\begin{array}{c}\text { Vitally } \\
\text { Important }\end{array}$ & $\begin{array}{c}\text { Rating } \\
\text { Average }\end{array}$ & $\begin{array}{c}\text { Response } \\
\text { Count }\end{array}$ \\
\hline $\begin{array}{l}\text { Collection includes item(s) } \\
\text { for which there is a } \\
\text { preservation concern or to } \\
\text { make fragile item(s) more } \\
\text { accessible to the public }\end{array}$ & 0 & 1 & 9 & 22 & 9 & 3.95 & 41 \\
\hline $\begin{array}{l}\text { Collection includes } \\
\text { unique items }\end{array}$ & 0 & 0 & 1 & 19 & 21 & 4.49 & 41 \\
\hline $\begin{array}{l}\text { Collection involves a whole } \\
\text { run of an information } \\
\text { resource (e.g., an entire } \\
\text { manuscript, newspaper } \\
\text { run, etc.) }\end{array}$ & 2 & 5 & 11 & 21 & 2 & 3.39 & 41 \\
\hline
\end{tabular}


(continued from previous page)

\begin{tabular}{|c|c|c|c|c|c|c|c|}
\hline $\begin{array}{l}\text { Answer Options } \\
\text { (41 responses total) }\end{array}$ & $\begin{array}{c}\text { Not } \\
\text { Important }\end{array}$ & $\begin{array}{l}\text { Less } \\
\text { Important }\end{array}$ & Neutral & Important & $\begin{array}{c}\text { Vitally } \\
\text { Important }\end{array}$ & $\begin{array}{c}\text { Rating } \\
\text { Average }\end{array}$ & $\begin{array}{c}\text { Response } \\
\text { Count }\end{array}$ \\
\hline $\begin{array}{l}\text { Collection includes the } \\
\text { integration of various } \\
\text { media (i.e., images, } \\
\text { documents, audio) into } \\
\text { a themed presentation }\end{array}$ & 7 & 11 & 17 & 6 & 0 & 2.54 & 41 \\
\hline $\begin{array}{l}\text { Collection has a direct tie } \\
\text { to educational programs } \\
\text { and initiatives (e.g., } \\
\text { university courses, } \\
\text { statewide education } \\
\text { programs, or K-12 } \\
\text { education) }\end{array}$ & 3 & 3 & 6 & 17 & 12 & 3.78 & 41 \\
\hline $\begin{array}{l}\text { Collection supports } \\
\text { scholarly communication } \\
\text { and/or management of } \\
\text { institutional content }\end{array}$ & 1 & 4 & 7 & 21 & 8 & 3.76 & 41 \\
\hline $\begin{array}{l}\text { Collection involves a } \\
\text { collaboration with } \\
\text { university colleagues }\end{array}$ & 1 & 3 & 9 & 18 & 10 & 3.83 & 41 \\
\hline $\begin{array}{l}\text { Collection involves a } \\
\text { collaboration with entities } \\
\text { external to the university } \\
\text { (e.g., public libraries, } \\
\text { historical societies, } \\
\text { museums) }\end{array}$ & 2 & 4 & 11 & 19 & 5 & 3.51 & 41 \\
\hline
\end{tabular}

16. From where have ideas originated for existing, published digital collections at your library? In other words, have one or more digital collections been the brainchild of one of the following? (Mark all that apply)

\begin{tabular}{lcc}
\hline Answer Options (41 responses total) & $\begin{array}{c}\text { Response } \\
\text { Percent }\end{array}$ & $\begin{array}{c}\text { Response } \\
\text { Count }\end{array}$ \\
\hline $\begin{array}{l}\text { Library subject liaison or staff working with teaching faculty } \\
\text { on a regular basis }\end{array}$ & 75.6 & 31 \\
Library administration & 65.9 & 27 \\
Special Collections, Archives, or library with a specialized collection & 92.7 & 38 \\
or focus & & 26 \\
Digitization program manager & 63.4 & 28 \\
University staff or faculty member outside the library & 68.3 & 21 \\
\hline An external donor, friend of the library, community user, etc. & 51.2 & \\
\hline
\end{tabular}


17. To whom are new projects first proposed to be evaluated for digitization consideration?

\begin{tabular}{lcc}
\hline Answer Options (38 responses total) & $\begin{array}{c}\text { Response } \\
\text { Percent }\end{array}$ & $\begin{array}{c}\text { Response } \\
\text { Count }\end{array}$ \\
\hline To an individual decision-maker & 23.7 & 9 \\
To a committee for review by multiple people & 42.1 & 16 \\
No formal process & 34.2 & 13 \\
\hline
\end{tabular}

18. How are approved projects ultimately prioritized?

\begin{tabular}{lcr}
\hline Answer Options (37 responses total) & $\begin{array}{c}\text { Response } \\
\text { Percent }\end{array}$ & $\begin{array}{c}\text { Response } \\
\text { Count }\end{array}$ \\
\hline By a single decision-maker & 18.9 & 7 \\
By a committee for review by multiple people & 54.1 & 20 \\
By departments or groups outside of the library & 0.0 & 0 \\
No formal process & 27.0 & 10 \\
\hline
\end{tabular}

19. Are digitization program mission statements, selection criteria, or specific prioritization procedures in use?

\begin{tabular}{lcc}
\hline Answer Options (40 responses total) & $\begin{array}{c}\text { Response } \\
\text { Percent }\end{array}$ & $\begin{array}{c}\text { Response } \\
\text { Count }\end{array}$ \\
\hline Yes, one or more of these forms of documentation exist & 67.5 & 27 \\
detailing process & & 10 \\
Yes, some criteria are used but no formal documentation exists & 25.0 & 3 \\
No documented process in use & 7.5 & \\
\hline
\end{tabular}

20. What general evaluation criteria do you employ to measure how successful a typical digital project is? (Mark all that apply)

\begin{tabular}{lcc}
\hline Answer Options (39 responses total) & $\begin{array}{c}\text { Response } \\
\text { Percent }\end{array}$ & $\begin{array}{c}\text { Response } \\
\text { Count }\end{array}$ \\
\hline $\begin{array}{l}\text { Log analysis showing utilization/record views of digital } \\
\text { collection items }\end{array}$ & 69.2 & 27 \\
$\begin{array}{l}\text { Analysis of feedback or survey responses associated with the } \\
\text { digital collection }\end{array}$ & 38.5 & 15 \\
$\begin{array}{l}\text { Publicity generated by, or citations referencing, digital collection } \\
\text { E-commerce sales or reproduction requests for digital images }\end{array}$ & 46.2 & 18 \\
We have no specific evaluation measures in use & 12.8 & 5 \\
\hline
\end{tabular}


21. Has your institution been the recipient of a grant or gift whose primary focus was to help efforts geared toward digitization of a particular collection or to support the overall efforts of the digitization program?

\begin{tabular}{lcc}
\hline Answer Options (39 responses total) & $\begin{array}{c}\text { Response } \\
\text { Percent }\end{array}$ & $\begin{array}{c}\text { Response } \\
\text { Count }\end{array}$ \\
\hline $\begin{array}{l}\text { We have received one or more smaller grants or donations (each of } \\
\text { which was } \$ 100,000 \text { or less) to support a digital collection/program } \\
\begin{array}{l}\text { We have received one or more larger grants or donations (each } \\
\text { of which was greater than } \$ 100,000) \text { to support a digital } \\
\text { collection/program }\end{array}\end{array}$ & 23.1 & 9 \\
$\begin{array}{l}\text { We have received a mix of small and large grants or donations to } \\
\text { support a digital collection/program }\end{array}$ & 25.6 & 10 \\
$\begin{array}{l}\text { We have been unsuccessful in receiving grants or have not applied } \\
\text { for any grants-grants and/or donations have not played any role } \\
\text { whatsoever in supporting a digital collection or our digitization program }\end{array}$ & 46.2 & 18 \\
\hline
\end{tabular}

22. How would you rate the overall level of buy-in for collaborative digitization projects between the library and external partners (an external partner is someone not on the full-time library staff payroll, such as other university colleagues, colleagues from other universities, etc.)?

\begin{tabular}{lcc}
\hline Answer Options (41 responses total) & $\begin{array}{c}\text { Response } \\
\text { Percent }\end{array}$ & $\begin{array}{c}\text { Response } \\
\text { Count }\end{array}$ \\
\hline Excellent & 41.5 & 17 \\
Good & 39.0 & 16 \\
Neutral & 4.9 & 2 \\
Minimal & 7.3 & 3 \\
Low or None & 0.0 & 0 \\
Not applicable-our library has not yet published or attempted to publish & & 3 \\
a collaborative digital project involving individuals outside \\
the library
\end{tabular}

23. When considering the content available for digitization, which of the following statements apply? (Mark all that apply)

\begin{tabular}{lcc}
\hline Answer Options (40 responses total) & $\begin{array}{c}\text { Response } \\
\text { Percent }\end{array}$ & $\begin{array}{c}\text { Response } \\
\text { Count }\end{array}$ \\
\hline $\begin{array}{l}\text { At my institution, there is a lack of suitable library collections for } \\
\text { digitization }\end{array}$ & 0.0 & 0 \\
$\begin{array}{l}\text { Content providers regularly contact the digitization program with project } \\
\text { ideas }\end{array}$ & 52.5 & 21 \\
$\begin{array}{l}\text { The main source of content for new digitization projects comes from } \\
\text { Special Collections, archives, other libraries with specialized collections } \\
\text { (maps, music, etc.), or local cultural organizations (historical societies, } \\
\text { museums) }\end{array}$ & 87.5 & 35
\end{tabular}


(continued from previous page)

\begin{tabular}{lcc}
\hline Answer Options (40 responses total) & $\begin{array}{c}\text { Response } \\
\text { Percent }\end{array}$ & $\begin{array}{c}\text { Response } \\
\text { Count }\end{array}$ \\
\hline $\begin{array}{l}\text { The main source of content for new digitization projects comes from } \\
\text { born digital materials (such as dissertations, learning objects, or faculty } \\
\text { research materials) }\end{array}$ & 32.5 & 13 \\
$\begin{array}{l}\text { Content digitization is mainly limited by available resources (lack of } \\
\text { staffing, space, equipment, expertise) }\end{array}$ & 47.5 & 19 \\
Obtaining good content for digitization can be challenging & 7.5 & 3 \\
\hline
\end{tabular}

24. Various types of expertise are important in collaborative digitization projects. Please rate the level of your local library staff's expertise in the following areas (1-5 scale, with 1 having no expertise and 5 having tremendous expertise).

\begin{tabular}{|c|c|c|c|c|c|c|c|c|}
\hline $\begin{array}{l}\text { Answer Options } \\
\text { (41 responses } \\
\text { total) }\end{array}$ & $\begin{array}{c}\text { No } \\
\text { Expertise }\end{array}$ & $\begin{array}{c}\text { Very } \\
\text { Limited } \\
\text { Expertise }\end{array}$ & $\begin{array}{l}\text { Working } \\
\text { Knowledge/ } \\
\text { Enough to } \\
\text { "Get By" }\end{array}$ & $\begin{array}{c}\text { Advanced } \\
\text { Knowledge }\end{array}$ & $\begin{array}{c}\text { Tremendous } \\
\text { Expertise }\end{array}$ & N/A & $\begin{array}{c}\text { Rating } \\
\text { Average }\end{array}$ & $\begin{array}{c}\text { Response } \\
\text { Count }\end{array}$ \\
\hline $\begin{array}{l}\text { Digital imaging/ } \\
\text { document } \\
\text { scanning, } \\
\text { post image } \\
\text { processing, } \\
\text { photography }\end{array}$ & 0 & 1 & 3 & 21 & 16 & 0 & 4.27 & 41 \\
\hline $\begin{array}{l}\text { Metadata } \\
\text { creation/ } \\
\text { cataloging }\end{array}$ & 0 & 0 & 2 & 20 & 18 & 0 & 4.40 & 40 \\
\hline $\begin{array}{l}\text { Archival research } \\
\text { of documents } \\
\text { included in a } \\
\text { collection }\end{array}$ & 0 & 2 & 6 & 15 & 16 & 2 & 4.15 & 41 \\
\hline $\begin{array}{l}\text { Administration } \\
\text { of the hosting } \\
\text { server }\end{array}$ & 1 & 2 & 7 & 16 & 15 & 0 & 4.02 & 41 \\
\hline $\begin{array}{l}\text { Grant writing/ } \\
\text { donor cultivation }\end{array}$ & 1 & 4 & 13 & 13 & 8 & 2 & 3.59 & 41 \\
\hline $\begin{array}{l}\text { Project } \\
\text { management }\end{array}$ & 0 & 1 & 9 & 23 & 8 & 0 & 3.93 & 41 \\
\hline $\begin{array}{l}\text { Multimedia } \\
\text { formats }\end{array}$ & 0 & 5 & 21 & 10 & 4 & 1 & 3.33 & 41 \\
\hline $\begin{array}{l}\text { Database } \\
\text { design and data } \\
\text { manipulation }\end{array}$ & 0 & 4 & 9 & 14 & 13 & 1 & 3.90 & 41 \\
\hline
\end{tabular}




\begin{tabular}{lcccccccc}
\hline $\begin{array}{l}\text { Answer Options } \\
\text { (41 responses } \\
\text { total) }\end{array}$ & $\begin{array}{c}\text { No } \\
\text { Expertise }\end{array}$ & $\begin{array}{c}\text { Very } \\
\text { Limited } \\
\text { Expertise }\end{array}$ & $\begin{array}{c}\text { Working } \\
\text { Knowledge/ } \\
\text { Enough to } \\
\text { "Get By" }\end{array}$ & $\begin{array}{c}\text { Advanced } \\
\text { Knowledge }\end{array}$ & $\begin{array}{c}\text { Tremendous } \\
\text { Expertise }\end{array}$ & $\begin{array}{c}\text { N/A } \\
\text { Rating } \\
\text { Average }\end{array}$ & $\begin{array}{c}\text { Response } \\
\text { Count }\end{array}$ \\
\hline $\begin{array}{l}\text { Digital asset } \\
\text { management } \\
\text { software (e.g., } \\
\text { CONTENTdm) }\end{array}$ & 3 & 0 & 5 & 21 & 11 & 0 & 3.93 & 40 \\
$\begin{array}{l}\text { Programming } \\
\text { languages }\end{array}$ & 4 & 3 & 14 & 9 & 11 & 0 & 3.49 & 41 \\
$\begin{array}{l}\text { Web design and } \\
\text { development }\end{array}$ & 2 & 1 & 13 & 10 & 15 & 0 & 3.85 & 41 \\
$\begin{array}{l}\text { Usability } \\
\text { Marketing and }\end{array}$ & 1 & 7 & 12 & 13 & 8 & 0 & 3.49 & 41 \\
Promotion & 2 & 11 & 17 & 7 & 3 & 1 & 2.95 & 41 \\
\hline
\end{tabular}

25. What are some of the factors that you feel have contributed to the success of your institution's digitization program?

Survey responses were quite diverse because respondents were speaking to their own perceptions and institutional experience. The general trend of responses are discussed in the body of the paper.

26. What are the biggest challenges for your institution's digitization program?

Survey responses were quite diverse because respondents were speaking to their own perceptions and institutional experience. The general trend of responses are discussed in the body of the paper.

\section{APPENDIX B. White paper organization}

I. Introduction

II. Current Status of Digitization Projects at the UNLV Libraries

III. Topic 1: Program Planning

A. Are there boundaries to the Libraries digitization program? What should the program support?

B. What resources are needed to realize program goals?

C. Who is the user or audience?

D. When selecting and designing future projects, how can high-quality information be presented in online formats incorporating new features while remaining un-biased and accurate in service provision?

E. To what degree do digitization initiatives need their own identity versus heavily integrating with the Libraries' other online components, such as the general website?

F. How do the libraries plan on sustaining and evaluating digital collections over time?

G. What type of authority will review projects at completion? How will the project be evaluated and promoted?

IV. Topic 2: Initiative Selection and Prioritization

A. Project Selection: What content criteria should projects fall within in order to be considered for digitization and what is the justification for conversion of the proposed materials? 
B. Project Selection: What technical criteria should projects fall within in order to be considered for digitization?

C. Project Selection: How does the project relate to, interact with, or complement other published projects and collections available globally, nationally, and locally?

D. Project Selection and Prioritization: After a project meets all selection criteria, resources may need to be evaluated before the proposal reaches final approval. What information needs to be discussed in order to finalize the selection process, select between qualified project candidates, and begin the prioritization process for approved proposals?

E. Project Prioritization: Should we develop a formal review process?

V. Topic 3: Project Planning

A. What are the planning steps that each project requires?

B. Who will be responsible for the different steps in the project plan and department workload?

C. How can the Libraries provide rich metadata and useful access points?

D. What type of Web design will each project require?

E. What type of communication needs to exist between groups during the project?

VI. Concluding Remarks

VII. Related Links and Resources Cited

VIII. White Paper Appendixes
A. Working List of Advisory Committee Functions and Project Workgroup Functions
B. CONTENTdm Software: Roles and Expertise
C. Project Team Workflow
D. CONTENTdm Elements

\section{APPENDIX C. First workshop questions}

\section{General questions}

1. How do you define a digital library? Do the terms "repository," "digital project," "exhibit," or "online collection" connote different things? If so, what are the differences, similarities, and boundaries for each?

2. What factors have contributed to a successful digitization program at your institution? Did anything go drastically wrong? Were there any surprises? What should new digitization programs be cautious and aware of?

3. What is the role, specifically, of the academic library in creating digital collections? How is digitization tied to the mission of your institution?

4. Why digitize and for whom? Do digital libraries need their own mission statement or philosophy because they differ from physical collections? Should there be boundaries to what is digitized?

5. What standards are most widely in use at this time? What does the future hold? Are there new standards you are interested in?

\section{Technical questions, metadata questions}

1. What are some of the recommended components of digital library infrastructure that should be in place to support a digitization program (equipment, staff, planning, technical expertise, content expertise, etc?)

2. What are the relationships between library digitization initiatives, the library website, the campus website or portal, and the Web? In what ways do these information sources overlap, interoperate, or require boundaries?

3. How do you decide on what technology to use? What is the decision-making process when implementing a new technology?

4. Standards are used in various ways during digitization. What is the importance of using standards, and are there areas where standards should be relaxed, or not used at all? How do digitization programs deal with evolving standards?

5. Preservation isn't talked about as much as it used to be. What's your solution or strategy to the problem of preserving digital materials?

6. Will embedded metadata ever be the norm for digital objects, or will we continue to rely on collection management like CONTENTdm to link digital objects to their associated metadata? 


\section{Collections and design questions}

1. How do you decide what should be included in a digital library? Does the digital library need a collection development policy and if so, what type? How are projects prioritized at your institution?

2. How do you decide who your user is? Are digital libraries targeting mobile users or other users with unique needs? What value-added material compliments and enhances digital collections (i.e., item-level metadata records, guided searches, narrative or scholarly content, teaching material, etc.)?

3. How should digital libraries be assessed and evaluated? How do you gauge the success of a digital collection, exhibit, or library? What has been proven and disproved in the short time that libraries have been doing digital projects?

4. What role do digital libraries play in marketing the library? How do you market your digital collections? Are there any design criteria that should be considered for the Web presence of digital libraries (should the digital library look like the library website, the campus website, or have a unique look and feel)?

5. Do you have any experience partnering with teaching faculty to create digital collections? How are collaborations initiated? Are such collaborations a priority? What other types of collaborations are you involved in now? How do you achieve consensus with a diverse group of collaborators? To what degree is centralization important or unnecessary?

\section{APPENDIX D. Second workshop outline}

1. Introduction-purpose/focus of the meeting

A. To talk about next steps in the digitization program

B. Quick review of the current status and where the program has been

C. Serve to further educate participants on the steps involved in taking a project idea to reality

D. Goals for Participants: understand types of projects and project prioritization; engage in activities on ideas and prioritization; talk about process and discuss committee; open forum

2. Staff Digitization Survey Discussion
A. "Defining Digital Libraries"
B. "Boundaries to the Digitization Program"
C. "Users and Audience"
D. "Digital Project Design"
E. "Potential Projects and Ideas"

3. First Group Exercise: Digital Project Idea Ranking and Defense of Ranking

4. Second Group Exercise: Digital Project Idea Brainstorming and Defense of Ideas Brainstormed

5. Concept/Proposal for a Digitization Advisory Committee

6. Conclusion and Next Steps 